\title{
AIR-ASSISTED BOOM SPRAYER AND SPRAY DEPOSITION ON BEAN PLANTS
}

\author{
Fernando Cesar Bauer ${ }^{1,2 *}$; Carlos Gilberto Raetano ${ }^{1}$ \\ ${ }_{2}^{I}$ UNESP /FCA-Depto. de Produção Vegetal/Defesa Fitossanitária, C.P. 237 - 18603-970 - Botucatu, SP - Brasil. \\ ${ }^{2}$ FAPESP scholarship. \\ *Corresponding author <fernandobauer@fca.unesp.br>
}

\begin{abstract}
The development of safe pesticide application techniques with low volume rates, frequency and spray drift, along with the need to obtain better control level of crop pest control levels, justify the airassistance in boom sprayers. The aim of this research was to evaluate the spray deposition on bean plants with different nozzles and volume rates by air-assisted and non-assisted sprayers. A completely randomized experiment was carried out using copper oxide as a tracer (50\% metalic copper) for deposit evaluation. The artificial targets were fixed on the upper and under-side of the leaflets, at the top and lower third of the same plants under the spray boom. After application, targets were washed individually with an extracting solution of nitric acid $\left(1.0 \mathrm{~mol} \mathrm{~L}^{-1}\right)$. The tracer deposition on the artificial targets was quantified by atomic absorption spectrofotometry. The effects of air-assisted spray were not significant in relation to spray deposition 48 days after emergence of the bean plants.
\end{abstract}

Key words: Phaseolus vulgaris, application technique, tracer, boom sprayer

\section{ASSISTÊNCIA DE AR EM BARRA DE PULVERIZAÇÃO E A DEPOSIÇÃO DA CALDA EM FEIJOEIRO}

\begin{abstract}
RESUMO: A possibilidade do desenvolvimento de técnicas de aplicação de produtos fitossanitários mais seguras, com menores volumes de calda, número de aplicações e deriva, aliados à necessidade de se obter melhores níveis de controle dos agentes nocivos às plantas cultivadas, justificam o uso da assistência de ar junto à barra de pulverização. Com o objetivo de avaliar a deposição da pulverização na cultura do feijoeiro (Phaseolus vulgaris), em presença e ausência da assistência de ar junto à barra de pulverização, com diferentes pontas de pulverização e volumes de calda, foi conduzido um experimento em delineamento inteiramente casualizado, utilizando-se como traçador o óxido cuproso. Alvos artificiais (papel filtro com $3 \times 3 \mathrm{~cm}$ ) foram afixados nas superfícies adaxial e abaxial de folíolos posicionados nos terços superior e inferior de plantas, selecionadas ao acaso, distribuídas perpendicularmente ao deslocamento do pulverizador. Após a aplicação do traçador os coletores foram lavados individualmente em solução extratora de ácido nítrico a $1,0 \mathrm{~mol} \mathrm{~L}^{-1}$. A determinação quantitativa dos depósitos foi realizada com o uso da espectrofotometria de absorção atômica. A assistência de ar junto à barra de pulverização não aumentou a deposição do traçador em folíolos de feijoeiro, aos 48 dias após a emergência da cultura.

Palavras-chave: Phaseolus vulgaris, técnica de aplicação, traçador, pulverizador de barras
\end{abstract}

\section{INTRODUCTION}

Recent years have witnessed the constant development of agricultural sprayers, with the availability of accessories such as electronic controls, GPS, plant sensors and air assistance along the spray boom. However, little is known about these modifications in relation to the efficiency of the pest and disease control (Van de Zande et al., 1994).

Bearing in mind that many insects and pathogens develop on the abaxial surface of bean plant leaves, becoming targets that are difficult to be reached with conventional sprays (without air assistance), a more detailed study on the use of air assistance along the boom could lead to better control levels. The use of this technique can also contribute towards a reduction in the rates of agro- chemicals, even though more research and development is required to accomplish the task (Cooke et al., 1990). The use of air assistance increased the deposition of herbicide applications on the bottom surface of leaves in sugar beets (May, 1991). Similar results were obtained by Bauer \& Raetano (2000), who observed a better deposition on the bottom parts of soybean plants when air assistance was utilized on the boom.

These facts have been scarcely discussed and reported in the literature, but are of fundamental importance for the control of the whitefly (Bemisia spp.) and, consequently, in decreasing the incidence of the bean golden mosaic virus. Chemical control is the main method utilized against the whitefly and, undoubtedly, has experienced little success, since year after year the pest reappers 
with increased tolerance to insecticides. This happens because of the inefficiency of the methods of application of chemicals ordinarily used, among other factors (Omer et al., 1997). Chemical control has not been considered a satisfactory practice so far because of the low efficiency of the application methods in delivering the product to the lower face of leaves, to expose nymphs and adults to direct contact with the product (Servín-Villegas et al., 1997).

Therefore, the objectives of this work were to estimate the effect and influence of air assistance along the boom, on spray deposition on the adaxial and abaxial surfaces of bean plant leaflets, with different types of spraying nozzles.

\section{MATERIAL AND METHODS}

Two hectares of bean plants, variety Carioca, grown in Iracemápolis-SP, Brazil $\left(22^{\circ} 39^{\prime} 45^{\prime} \mathrm{S}\right.$ and $47^{\circ}$ $31^{\prime} 26$ " W) were utilized in the experiment. Sowing was performed leaving $0.5 \mathrm{~m}$ spacing between planting rows and 14-15 seeds per linear meter, therefore achieving, at the time of applications, an estimated population of 250,000 plants $\mathrm{ha}^{-1}$. Fertilization, based on soil analysis, was made according to recommendation of Moraes (1988). Management practices were performed in similarly to those adopted in commercial crops, that is, evaluation of the necessity, or not, of insecticide or fungicide applications according to infestations and/or infections, except for the application of fungicides, since no cupric products of any type were utilized. Applications were carried out when plants were approximately $0.5 \mathrm{~m}$ high.

The experiment was carried out in October, 2000, 48 days after emergence (DAE) of plants, in a completely randomized design with 10 treatments and 25 replicates. Each plant, randomly selected within the spraying swath, was considered a replicate because of the great, localized variation of application that occurs with spraying bars.

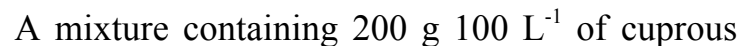
oxide was utilized in the applications, corresponding to $100 \mathrm{~g}$ of metallic copper. Treatments and their respective characteristics are shown in Table 1. Nozzles were selected based on the application volume, within the recommended pressure range. Two flat fans (AXI 11003 and AXI 110015) and 3 hollow cone nozzles (JA-0,5; JA-1 and JA-2) were also utilized.

A boom sprayer, equipped with a 14-m, air-assisted spraying bar, was utilized for all configurations established in this study, since this equipment is able to operate with or without air assistance along the boom. The operation speed, as determined by measuring with three replicates the time necessary to move $50 \mathrm{~m}$, was maintained at $6.0 \mathrm{~km} \mathrm{~h}^{-1}$ for all treatments, with the pressure varying according to the nozzle type.

Pressure adjustments and nozzle changes were performed before spraying each treatment, separately for each nozzle. After the necessary adjustments, the equipment would initiate the spray with air assistance turned off and before the begining of each plot, following with stabilized speed and flow rate. After finishing each plot, in an area without collectors set aside for maneuvering and with the equipment moving, the operator would turn on the air assistance, then spraying the next plot with air assistance activated and stabilized, interrupting the spray upon finishing the second plot. After finishing, in a different maneuver area, the tractor would come to a full stop and start the necessary adjustments to proceed to the next two treatments, involving other spray nozzles. This procedure allowed two spray operations to be performed under very similar environmental conditions, the only difference between the two treatments being the use, or not, of air assistance. Each plot and each maneuver area was $15 \mathrm{~m}$ wide and $15 \mathrm{~m}$ long. Table 2 shows the meteorological conditions under which spray operations were carried out.

Table 1 - Equipment and operational conditions during spraying on a bean crop at 48 DAE. 
Sample collecting, identical for all treatments, was performed with the use of artificial targets (filter paper pieces measuring $3 \times 3 \mathrm{~cm}$ ) distributed among 25 plants under the spray boom, oriented perpendicularly to the equipment movement. Four collectors were fastened to each of the 25 randomly selected plants, with one collector on the adaxial and another on the abaxial surface of the same leaflet, in the upper half of the plant. The same procedure was adopted for another leaflet located at the bottom half of the same plant. Collectors were removed immediately after each spray, individually packaged in properly identified plastic bags, and stored in a box with thermal insulation.

After finishing all treatments, the artificial targets were placed inside brown-glass containers with $10 \mathrm{~mL}$ of a nitric acid extracting solution at $1.0 \mathrm{~mol} \mathrm{~L}^{-1}$. After agitation for 15 minutes and resting for 24 hours, they were taken to the atomic absorption spectrophotometer to quantify the ion copper, a method successfully utilized by Chaim et al. (1999). Considering that the concentration of copper in the mixture was $990 \mathrm{mg} \mathrm{L}^{-1}$, it became possible to establish the liquid volume captured, by the following equation:

$$
\mathrm{C}_{\mathrm{i}} \mathrm{V}_{\mathrm{i}}=\mathrm{C}_{\mathrm{f}} \mathrm{V}_{\mathrm{f}}
$$

where: $\mathrm{C}_{\mathrm{i}}=$ concentration of copper in the mixture (mg $\left.\mathrm{L}^{-1}\right) ; \mathrm{C}_{\mathrm{f}}=$ concentration of copper detected by the atomic absorption spectrophotometer $\left(\mathrm{mg} \mathrm{L}^{-1}\right) ; \mathrm{V}_{\mathrm{i}}=$ volume captured by target $(\mathrm{mL}) ; \mathrm{V}_{\mathrm{f}}=$ sample dilution volume $(\mathrm{mL})$

Eight samples, were used to quantify the mixture concentration and were removed directly from the sprayer tank moments before the start and end of applications. The values of deposits in the collectors, in $\mu \mathrm{L} \mathrm{cm}^{-2}$, were submitted to analysis of variance and the means were compared by the Tukey test at 5\%.

The precision of the analytical method was evaluated by estimating the percentage of recovery of copper deposits in the targets. To accomplish this, 17 collectors identical to those utilized in the field were set aside and received the application of $1 ; 2 ; 4 ; 6 ; 8 ; 10 ; 12 ; 14 ; 16$; $18 ; 20 ; 25 ; 30 ; 35 ; 40 ; 45$ and $50 \mu \mathrm{L}$ of the same mixture utilized in the spray, through microsyringes. After the applied solution had dried out, targets were placed in glass containers with $10 \mathrm{~mL}$ of the same nitric acid extracting solution utilized for the targets collected in the field. The quantification of copper deposits in these targets was performed by using the same method as for targets collected in the field.

Coefficients of variation (CV) were observed and, after applying the Hartley Test to verify the homogeneity of variances, data were transformed to the "square root of $\mathrm{x}+0.5$ ". Values are presented in Tables 3 and 4 .

\section{RESULTS AND DISCUSSION}

Recovery of copper was close to $100 \%$. This demonstrates the reliability and precision of the chosen analytical method (Figure 1). In general, the air assistance along the boom did not provide an increase in the levels of deposits achieved by different spray nozzles (Table 3 ). Nozzles AXI 11003 in the presence and absence of air assistance, presented levels of deposits similar to those obtained with nozzle JA-2, as expected, since both sprayed nearly the same application volume. However, a different behavior was observed for the other nozzles, since nozzle JA-0.5, spraying an application volume equal to $60 \mathrm{~L} \mathrm{ha}^{-1}$, did not differ from nozzles AXI 110015 and JA-1, both applying more than $100 \mathrm{~L} \mathrm{ha}^{-1}$. The smallest quantitative volumes of deposits were those obtained with nozzles JA-1, contrary to what was expected, probably because of the negative influence of the environment, especially wind, at the time of application. Similar environment conditions were observed at application time with nozzles JA-1 and AXI 11003 (Table 2); however, the

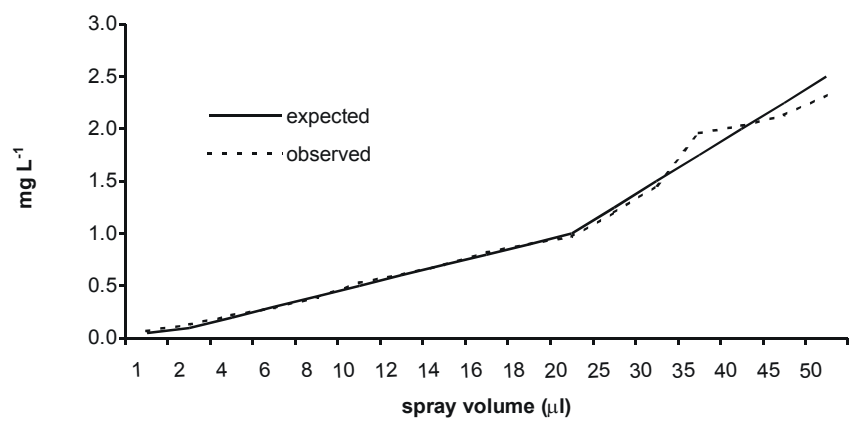

Figure 1 - Observed and expected recuperation of tracer in artificial targets.

Table 2 - Environmental conditions at time of application. 
Table 3 - Spray deposition on bean plants at 48 DAE, with and without air assistance at the spray boom.

${ }^{(1)}$ Numbers transformed to $\sqrt{\mathrm{x}+0.5}$. "Numbers in colums followed by the same letter do not differ by the Tukey test $(P=0.05)$.

Table 4 - Spray deposition in different places and leaflet surfaces after tracer application on a bean crop at 48 DAE, with and without air assistance.

\begin{tabular}{|c|c|c|c|c|c|}
\hline \multirow[t]{3}{*}{ Nozzle } & \multirow{3}{*}{$\begin{array}{l}\text { Application } \\
\text { Condition }\end{array}$} & \multicolumn{4}{|c|}{ Positions and surfaces in the plants } \\
\hline & & \multicolumn{2}{|c|}{ Upper } & \multicolumn{2}{|c|}{ bottom } \\
\hline & & adaxial & abaxial & adaxial & abaxial \\
\hline & & 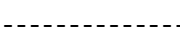 & $-\ldots$ & 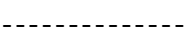 & $-\cdots$ \\
\hline \multirow[t]{2}{*}{ AXI 11003} & no air & $1.294^{(1)} \mathrm{e}^{*}$ & $0.742 \mathrm{abc}$ & $1.099 \mathrm{~d}$ & $0.738 \mathrm{~cd}$ \\
\hline & air-assisted & $1.253 \mathrm{de}$ & $0.761 \mathrm{abc}$ & $1.040 \mathrm{~cd}$ & $0.689 \mathrm{abc}$ \\
\hline \multirow[t]{2}{*}{ AXI 110015} & no air & $1.118 \mathrm{bcd}$ & $0.739 \mathrm{ab}$ & $0.863 \mathrm{a}$ & $0.741 \mathrm{~cd}$ \\
\hline & air-assisted & $1.090 \mathrm{abc}$ & $0.742 \mathrm{abc}$ & $0.911 \mathrm{abc}$ & $0.665 \mathrm{ab}$ \\
\hline \multirow[t]{2}{*}{ JA- 0.5} & no air & $0.966 \mathrm{a}$ & $0.680 \mathrm{a}$ & $0.906 \mathrm{ab}$ & $0.684 \mathrm{abc}$ \\
\hline & air-assisted & $1.039 \mathrm{ab}$ & $0.717 \mathrm{ab}$ & $0.907 \mathrm{ab}$ & $0.685 \mathrm{abc}$ \\
\hline \multirow[t]{2}{*}{ JA- 1} & no air & $1.037 \mathrm{ab}$ & $0.747 \mathrm{abc}$ & $0.886 \mathrm{ab}$ & $0.676 \mathrm{ab}$ \\
\hline & air-assisted & $1.013 \mathrm{ab}$ & $0.685 \mathrm{a}$ & $0.859 \mathrm{a}$ & $0.641 \mathrm{a}$ \\
\hline \multirow[t]{2}{*}{ JA-2 } & no air & $1.182 \mathrm{cde}$ & $0.826 \mathrm{c}$ & $1.002 \mathrm{bcd}$ & $0.777 \mathrm{~d}$ \\
\hline & air-assisted & $1.187 \mathrm{cde}$ & $0.772 \mathrm{bc}$ & $0.990 \mathrm{abcd}$ & $0.721 \mathrm{bcd}$ \\
\hline $\mathrm{CV}(\%)$ & & 13.95 & 13.00 & 15.56 & 9.52 \\
\hline Mds & & 0.139 & 0.086 & 0.132 & 0.060 \\
\hline
\end{tabular}

${ }^{(1)}$ Numbers transformed to $\sqrt{\mathrm{x}+0.5}$.

*Numbers in columns followed by the same letter do not differ by the Tukey test $(P=0.05)$.

negative interference could be noticed only for nozzles JA-1, because of the lower application volume relative to the other nozzle, and also because it produced small droplets, more propense to drift.

The hollow cone spray nozzles types JA-0.5; JA1 , and JA-2 at their respective working pressures, presented little variation in the volume of median diameter (vmd) of generated droplets, according to manufacturer's specifications, with a maximum value of $78 \mathrm{~mm}$ for droplets produced by nozzle JA-2 at $1,033.5 \mathrm{kPa}$, characterized as very fine (Matthews, 1992). Considering that the theoretical number of droplets $\mathrm{N}_{\mathrm{d}}$ produced in an area of one square centimeter can be expressed by Equation 2
(Hislop, 1987), it can be observed that, for droplets with close vmd values, the greater the application volume the greater the theoretical droplet density and, consequently, the greater the spray deposit;

$$
\mathrm{N}_{\mathrm{d}}=60 * \pi^{-1} *\left(100 * \mathrm{D}^{-1}\right)^{3} * \mathrm{Q}
$$

where: $\mathrm{D}=$ diameter of the droplet in micrometers; $\mathrm{Q}=$ application volume in $\mathrm{L} \mathrm{ha}^{-1}$.

The greatest application volume $\left(210 \mathrm{~L} \mathrm{ha}^{-1}\right)$ provided higher levels of deposits in the bean crop, regardless of sampling position in the plant. However, the deposits did not differ between treatments when applied at 60,110 or 104 liters of mix per hectare, even though this 


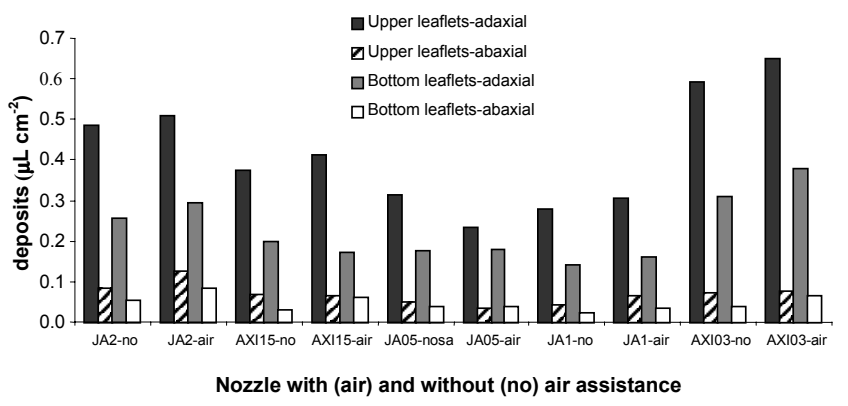

Figure 2 - Spray deposition on adaxial and abaxial surfaces of leaflets, in the upper and bottom half of bean plants and different nozzles with or without air assistance.

last volume is related to nozzle AXI 110015, which produces a different droplet standard relative to that yielded by the cone nozzle.

Larger deposits were also observed for larger application volumes sprayed when nozzles AXI 110015 and 11003 are compared at the same working pressure (Table $3)$. These results agree with those obtained by Cooke \& Hislop (1987), who reported that larger application volumes, under conventional spraying, provide higher levels of deposits on leaves located in the lower part of barley plants.

In general, 48 days after emergence, the mean values of tracer deposits in the upper part of bean plants did not differ in the presence or absence of air assistance, for the different nozzles being tested (Table 4 and Figure 2). Air assistance, under these experimental conditions, was not sufficient to improve deposition relatively to the conventional application (Table 4). This fact was also observed by Bauer \& Raetano (2000) during an evaluation of the effect of air assistance on the levels of spray deposits, in the upper part of soybean plants, even though they detected an increase in the bottom parts of the plants, which was not observed in the present study.

Larger application volumes provided higher levels of deposits on the adaxial surface of leaflets, closer to the spray (tip of the plant). However, this effect was not observed on the abaxial surface (Figure 2).

On the adaxial surface of leaves, closer to the soil, the levels of deposits for the configurations under test were very similar, with values around $50 \%$ of those obtained for this surface, but on the tip of the plant. Notwithstanding, on the abaxial surface, the values of deposits were very close to those obtained for this surface, when the evaluation was performed at the tip of the plant. In this case, specifically, air assistance allowed greater deposits to be obtained with nozzles AXI 110015 (Figure 2).

\section{CONCLUSIONS}

Air assistance along the spray boom did not increase deposition on bean plant leaves at 48 DAE; greater application volumes provided greater depositions on the entire bean plant; deposition on the abaxial surface of the upper leaflets was similar to that observed on leaflets closer to the soil.

\section{REFERENCES}

BAUER, F.C.; RAETANO, C.G. Assistência de ar na deposição e perdas de produtos fitossanitários em pulverizações na cultura da soja. Scientia Agricola, v.57, p.271-276, 2000.

CHAIM, A.; VALARINI, P.J.; OLIVEIRA, D. A.; MORSOLETO, R.V.; PIO, L.C. Avaliação de perdas de pulverização em culturas de feijão e tomate. Jaguariúna. Embrapa Meio Ambiente, 1999. 29p. (Boletim de Pesquisa).

COOKE, B.K.; HISLOP, E.C. Novel delivery systems for arable crop spraying - deposit distribution and biological activity. Aspects of Applied Biology, v.14, p.53-70, 1987.

COOKE, B.K.; HISLOP, E.C.; HERRINGTON, P.J.; WESTERN, N.M.; HUMPHERSON-JONES, F. Air-assisted spraying of arable crops, in relation to deposition, drift and pesticide performance. Crop Protection, v.9, p.303-311, 1990.

HISLOP, E.C. Can we define achieve optimum pesticide deposits? Aspects of Applied Biology, v.14, p.153-172, 1987.

MATTHEWS, G.A . Pesticide application methods. 2.ed. London: Longman, 1992. 405p.

MAY, M.J. Early studies on spray drift, deposit manipulation and weed control in sugar beet with two air-assisted boom sprayers. In: LAVERS, A.; HERRINGTON, P.; SOUTHCOMBE, E.S.E. (Ed.) AIR-ASSISTED SPRAYING IN CROP PROTECTION, Swansea, 1991. Proceedings. Swansea: BCPC, 1991. p.89-96. (BCPC Monograph, 46).

MORAES, J.F.V.; Calagem e adubação. In: ZIMMERMANN,M.J.O.; ROCHA,M, YAMADA,T. (Ed.) Cultura do feijoeiro-Fatores que afetam a produtividade. Piracicaba: Potafos, 1988. 589p.

OMER, A.D.; LEIGH, T.F.; GRANET, J. Insecticide resistance of greenhouse whitefly (Hom. Aleyrodidae) and fitness on plant hosts relative to the San Joaquim Valley (California) cotton agroecosystem. Journal of Applied Entomologist, v.113, p.240-251, 1997.

SERVÍN-VILLEGAS, R.; MARTINEZ, J.L.; TROYO-DIEGUEZ, E.; ORTEGA-RUBIO, A. Susceptibilidad de adultos de Bemisia argentifolii (Bellows\&Perring), a insecticidas de uso comum em Baja California Sur, Mexico. Southwestern Entomologist, v.22, p.91-101, 1997.

VAN DE ZANDE; J.C.; MEIER, R.; VAN IJZENDOORN, M.T. Air-assisted spraying in winter wheat-results of deposition measurements and the biological effect of fungicides against leaf and ear diseases. In: BRITISH CROP PROTECTION CONFERENCE - PESTS AND DISEASES, Brighton, 1994. Proceedings. Brighton: BCPC, 1994. p.313-318.

Received November 13, 2001 